\title{
A KIÉGÉSI SZINDRÓMA MEGELŐZÉSE - A HAGYOMÁNYOKTÓL A MODERN INFORMÁCIÓS TECHNOLÓGIÁKIG
}

\author{
SZÉNYEI GÁBOR ANDRÁS - ÁDÁM SZILVIA - \\ GYŐRFFY ZSUZSA - TÚRY FERENC
}

Semmelweis Egyetem, Magatartástudományi Intézet

e-mail: gabor@szenyei.hu; adamszilvia@hotmail.com;

gyorffy.zsuzsa@chello.hu; tury@t-online.hu

Beérkezett: 2014. szeptember 01. - Elfogadva: 2015. január 25.

Háttér és célkitűzés: A kiégés a segitő foglalkozásúak gyakori szindrómája, mely az egyéni terheken túl az egészségügyi ellátó rendszer nehézségeihez vezet. Megelözése alapvetö fontosságú egyéni és szervezeti szinten egyaránt. Áttekintö tanulmányunkban a kiégés megelözésének újabb módszereit összegezzük.

Módszer: Az utóbbi évtized irodalmi adatainak áttekintése. Elsősorban az újabb eljárásokat bemutató és hatékonyságot elemző kutatásokra támaszkodtunk (például az „e-mental health” terén végzett vizsgálatokra).

Eredmények: Az elsödleges, másodlagos és harmadlagos prevencióban gyakran alkalmaznak hagyományos módszereket (például relaxációkat, kognitív-viselkedésterápiás elemeket). Az újabb eljárások között említendők a stresszmenedzsment programjai, a mindfulness alkalmazása. A legmodernebb eszközök az új információs technológiák, amelyekkel egyre több prevenciós program él. Az új prevenciós stratégiák között ki kell emelni a prevenciós eszközök személyre szabott alkalmazását, valamint a szervezeti kultúra fejlesztését célzó programokat, amelyek egészségpolitikai lépések szükségességére is felhívják a figyelmet.

Következtetés: A kiégés megelözése a munkalélektanban és a segítö foglalkozások terén lényeges feladat a szakemberek védelme és az ellátás minősége, valamint az egészségügyi gazdaságosság szempontjából. A prevenciót szolgáló programok hatékonysága jó, bár még kevés randomizált, kontrollált vizsgálat készült.

Kulcsszavak: kiégés, munkastressz, megelözés, stresszmenedzsment, e-mental health 


\section{BEVEZETÉS}

A kiégés a krónikus stressz eredményeként létrejövő, emocionális kimerülésben (fizikai és érzelmi fáradtságban), deperszonalizációban (másoktól való elidegenedésben, ami közönyös, távolságtartó attitűddel jár) és teljesítménycsökkenésben (csökkent kompetenciaérzésben és produktivitásban) megnyilvánuló szindróma, amelyet elsősorban segítő foglalkozásúak között írtak le (FREUDENBERGER, 1974; MASLACH és LEITER, 1997). Kialakulását többféle elméleti megközelítés magyarázza (a részleteket illetően utalunk MészÁros [2012] jó hazai áttekintésére). Dinamikus, egymást erősítő ciklusokból álló folyamat, amelyet stresszorok váltanak ki (például a pozitív munkakörnyezet hiánya). Ha az egyén stresszkezelő módozatai elégtelenné válnak, kialakul a krónikus fizikai és érzelmi kimerülés állapota.

A kiégés legfontosabb, bár nem specifikus tünetei testi és lelki zavarokban nyilvánulhatnak meg. A krónikus stressz és a kiégés tünetei között szoros kapcsolat van. Amint a definícióban is láttuk, a kiégés a krónikus stressz következménye, így a kiégés tünetei hasonlítanak a krónikus stressz és depresszió tüneteihez, bár fontos különbségek is megfigyelhetők közöttük. A stressz határozott reakciókban nyilvánul meg, például hiperaktivitásban vagy tenni akarásban, míg a kiégés tehetetlenségérzést vált ki (ÁDÁM, 2013).

Áttekintő közleményünkben a kiégés prevenciójára vonatkozó, az egészségügyi dolgozókat érintő újabb (a 2000-es években közölt) irodalmi forrásokat foglaljuk össze - nem feledve, hogy a kiégési szindróma más foglalkozások körében is megjelenik. Egy-egy módszer hatékonyságának bemutatásakor nem kizárólag egészségügyi dolgozók között végzett vizsgálatokra hivatkozunk - ezzel utalunk arra, hogy az adott módszer az egészségügy területén is hasznos lehet. Nem tárgyaljuk részletesen a kiégésnek a hazai szakirodalomban már többször és alaposan bemutatott számos aspektusát. A prevenciós módszerek között külön tárgyaljuk a legújabbnak számító, robbanásszerű elterjedés előtt álló eljárásokat, a modern információs technológiák alkalmazását - annak ellenére, hogy e téren a kiégés prevenciójára vonatkozóan még kevés „evidence based” vizsgálat áll rendelkezésre.

\section{A KIÉGÉSI SZINDRÓMA AZ EGÉSZSÉGÜGYI DOLGOZÓK KÖZÖTT}

A segítő foglalkozások egészségügyi terhei jól ismertek. Hazai adatok szerint a negyven év fölötti orvosok halandósága felülmúlja a lakosság halálozási mutatóit (GYŐRFFY és ÁDÁM, 2004). Az egészségügyben dolgozók között a pszichiátriai morbiditás jelentősen magasabb, mint az átlagnépességben. Az öngyilkossági ráta is magas, különösen a nőorvosok között (HEM és mtsai, 2004). Mindezek hátterében a feldolgozatlan stressznek nagy lehet a szerepe. Ennek okai lehetnek: a hivatással járó érzelmi involválódás, a műhibaperek, az egészségügy elüzletiesedése, a betegek növekvő elvárásai, a rohamosan bővülő ismeretanyag, az adminisztrációs kényszer, az időhiány, nem megfelelő javadalmazás, értékrendbeli ütközések 
(Maslach és Leiter, 1997; Shanafelt, Sloan és Habermann, 2003). A hivatásbeli stresszel kapcsolatos öngyilkossági veszélyre vonatkozóan PAPP és LÁNG (2013) segítő foglalkozásúak szerepét vizsgálta a prevencióban. 102 tanár kiégésmutatóit és az öngyilkossággal kapcsolatos ismereteit vetették össze egy másik kutatás során kapott eredményekkel (SUSÁNSZKY, HAJNAL és KOPP, 2008), amelyben segítő foglalkozásúakat és az átlagnépességet elemezték. Az eredmények arra utaltak, hogy a tanárok ismeretei szerényebbek voltak a témakörben, mint a segítő foglalkozásúaké, de jobbak, mint az átlagnépességé.

A kiégés jelei már az orvosi tanulmányok során megmutatkoznak. Egy hazai felmérés alapján a frissen végzett fiatal orvosok 30\%-a magas kiégési szinttel volt jellemezhető, s egynegyedük pszichoszomatikus panaszokkal küzdött (PAPP és TÚRY, 2010). A korai kiégés mérésére WIGGLETON és munkatársai (2010) orvostanhallgatók számára fejlesztettek ki egy 55 tételes kérdőívet, amely az erkölcsi distresszt méri (ennek definíciója: negatív érzelmek keletkeznek, ha valaki ismeri az erkölcsileg helyes teendőt, de nem cselekedhet a hierarchiák szorításában). A hallgatók a leírt helyzetek felét legalább egyszer már átélték.

Nemzetközi adatok szerint az érzelmi kimerülés orvosok között $20 \%$ körüli (áttekintés: MAJOR, REss, HUlesch és TÚRY, 2006). A magyar orvosok között a kiégési szindróma gyakorisága 21,2\% volt egy felmérésben (ÁDÁM, GYŐRFFY és Csовотн, 2006). Egy másik, 1333 fős egészségügyi szakdolgozói mintán végzett kutatás során a súlyos depresszió prevalenciája 5,6\% volt, a minta felére súlyos teljesítménycsökkenés volt jellemző (Mészáros, Cserháti, Oláh, Perczel FoRINTOS és ÁDÁM, 2013). DYRBYE és munkatársai (2013) az orvosok elégedettségét és kiégéstüneteit a karrier állomásai szempontjából értékelték. A karrier középső szakasza a leginkább kockázatos időszak. A karrierrel való elégedettség elősegítését és a kiégés csökkentését célzó programoknak figyelembe kell venniük ezt a tényezőt is.

Az orvosi szakágak között vannak nagyobb kiégési kockázattal jellemezhető területek. Például sebész-onkológusok között a kiégés prevalenciája igen magas: egy vizsgálatban 42\%-os, míg a pszichiátriai morbiditás $27 \%$, s a magas életminőség hiánya 54\% volt (GUEST és mtsai, 2011). A sebészek preferenciái a számba jövő prevenciós és intervenciós lehetőségeket tekintve: fitnessprogram, táplálkozási tanácsadás, a kollegiális szocializáció javítása. A kiégés szempontjából különösen nehéz egészségügyi terep a hospice szolgálat és a palliatív orvoslás is (SWETZ, HARrington, MATSUYAMA, SHANAFELT és LyCKHOlm, 2009).

A pszichiáterek kiégési kockázata jól ismert, hiszen a segítő hivatások egyik kiemelt területét képviselik. Pszichiáterek között végzett hazai felmérés szerint a kiégés dimenziói közül a teljesítménycsökkenés magas szintje a férfiak 40\%-ában, a nők 36\%-ában volt kimutatható. Az emocionális kimerülés magas foka a férfiak 31\%-ára, a nők 25\%-ára, míg a deperszonalizáció a férfiak 24\%-ára, a nők 15\%-ára volt jellemző (HARMATTA, ÁdÁM, GYŐRFFY, TÚRY és SZÉNYEI 2010). Egészségi állapotukra vonatkozóan kiderült, hogy közöttük a krónikus betegségek aránya magasabb, mint az átlagnépességé (ÁDÁm és mtsai, 2010).

A kiégés veszélye természetesen nemcsak orvosokra, hanem az egészségügyi személyzet tagjaira is vonatkozik. Ápolók között a következő stresszorok bizonyul- 
tak a kiégés prediktorainak: nem, életkor, munkában eltöltött idő, egynél több munkahely, vezetői beosztás, munkahelyi elégedettség, ellenálló-képesség, a munka-család egyensúlya (Queiros, Carlotto, Kaiseler, Dias és Pereira, 2013).

\section{A KIÉGÉSI SZINDRÓMA MEGELŐZÉSE}

A kiégés prevenciója szervezetpszichológiai szempontból szervezeti, vagy egyéni szintű lehet. Az előbbihez tartozik például a jobb munkafeltételek biztosítása, a munkahelyi stresszkezelés, míg az utóbbihoz többek között a relaxációs technikák, az önfejlesztés és az önismeret növelése, a stresszoldó technikák gyakorlása, szupervíziós segítség biztosítása, valamint a testmozgás is (ÁDÁM, TORZSA, GYŐRFFY, Vörös, Kalabay, 2009; EdWARds és Burnard, 2003; PÁlfi, Németh, Kerekes, Kállai és Bethlehem, 2008; PÁlfiné Szabó, VRanesicsné Horváth, NÉmeth és BETHLEHEM, 2007). A prevenciós és intervenciós programok gyakran összemosódnak, azaz a megelőzésben sok olyan módszer van, amelyet a kiégés kezelésében is használnak (MÉSZÁros, 2012). Megjegyzendő, hogy a fenti szempontok egy része általános munkaegészségbeli tényező (például a munkafeltételek), mások az egészségügyre specifikusak (ilyen az önismeret növelése), bár ezek között is vannak átfedések: a jobb önismeret nem csupán a segítő foglalkozásokban, hanem a vállalati felsővezetők között is prevenciós jelentőségű.

A megelőzés felosztásának másik szempontja az egészség-betegség dimenziójára vonatkozik. Az elsődleges megelőzést szolgáló stresszmenedzsment az egészség fenntartását célozza egészséges személyek között, a másodlagos megelőzés a kockázatnak kitett személyekre vonatkozik, a korai felismerést és korai intervenciókat jelenti, a harmadlagos megelőzés pedig a manifeszt kiégéstünetekkel rendelkezők számára biztosítja a progresszió megakadályozását (GÜNTHNER és BATRA, 2012). Ehhez hasonló felosztás a proaktív-reaktív stratégiák megkülönböztetése (az előbbiek az elsődleges megelőzést célzó „előremenő”, az utóbbiak a már kialakult zavarokra reagáló, azok csökkentését szolgáló stratégiák). A stresszmenedzsment a környezetre (stresszt jelentő helyzetekre, munkahelyre) és a személyekre is vonatkozhat. A környezeti stresszhelyzetek lehetnek általánosak, mint például a mindennapi megterhelések. A specifikus stresszorok között vannak operacionális és szervezeti stresszorok. Az előbbiek a hivatásbeli tevékenységekkel függenek össze, az utóbbiak pedig a hivatás gyakorlásának kontextusától (például kevés jövedelem, hiányos elismerés).

A primer prevenciós intervenciók általánosságban a stresszforrások kiküszöbölését célozzák. Idetartozik a munkakör újratervezése, vagy a munkatársi támogató csoportok. A szekunder prevenció intervenciói a stressztünetek csökkentésére irányulnak: különböző kognitív-viselkedésterápiás módszerek, meditáció, relaxáció, légzésgyakorlatok, biofeedback tréning, testgyakorlatok, naplóvezetés, időmenedzsment. A leghatékonyabb módszerek a kognitív-viselkedésterápiás elemek, a multimodális programok, a relaxációs módszerek, a szervezetre fókuszáló intervenciók, valamint az alternatív módszerek, mint a testgyakorlatok (RICHARDSON és Rothstein, 2008; VAn der Klink, Blonk, Schene és VAn Dijk, 2001). 
A következőkben a kiégésmegelőzést történeti szempont alapján tárgyaljuk, mert a fenti felosztási elvek az egyes vizsgálatokban nehezen választhatók el egymástól (az alkalmazott módszerek egyszerre szolgálhatják az elsődleges és a másodlagos prevenciót is).

\section{A stresszmenedzsment a kiégésmegelözés szolgálatában - a hagyományos módszerek értéke}

Amint láttuk, a kiégés megelőzésének fontos terepe a stresszmenedzsment. A személyre vonatkozó munkastressz egyik lényeges forrása, ha a személy a követelményeknek nem tud megfelelni, mert alapvető tapasztalatai vagy magatartásmódjai hiányzanak. Proaktív kognitív-viselkedésterápiás alapú stresszmenedzsment programok segíthetnek ilyen esetekben, például a kompetenciaérzés javításában és a beállítódások megváltoztatásában. A reaktív stresszcsökkentő technikák között a „klasszikussá” vált relaxációs és meditációs gyakorlatok a legismertebbek.

A protektív környezeti hatások között igen fontosak a közeli kapcsolatokra vonatkozó elemek: a jól funkcionáló családi háttér, a szeretetteli partnerkapcsolat, a támogató környezet és a biztonságos munkahely. A szociális háló és a személyes kapcsolatok protektív hatására utal SwETz és munkatársai (2009) fent említett kutatása is: a hospice szolgálatban és a palliatív orvoslásban dolgozó 40 szakorvost online kérdőív segítségével arról kérdeztek, hogy milyen stratégiákat alkalmaznak a kiégés megelőzésére. A leggyakoribb stratégia a testi jóllét biztosítása (60\%), majd a szakmai kapcsolatok ápolása (57\%), a transzcendentális perspektíva felvétele (43\%), a másokkal való beszélgetés (43\%), a hobbik (40\%), a változatos klinikai munka (37\%), a személyes kapcsolatok ápolása (37\%). A szabadidős tevékenységek jelentősen csökkentik a munkastresszt. Azok a személyek, akik az aktív szabadidős időtöltésekkel, testedzéssel, kreatív tevékenységekkel (hobbikkal) éltek és társas aktivitásuk jobb volt, szignifikánsan jobb alvásról, a munkaperiódusok közötti jobb felépülésről, valamint kevesebb krónikus, maladaptív fáradtsági tünetről számoltak be (WINWOOD, BAKKER és WINEFIELD, 2007).

Több vizsgálat kiemeli a problémafókuszú megoldási módok hatékonyságát a kiégés megelőzésében. Ilyen módszer a kognitív átstrukturálás, amely elősegíti a kiégés különböző tüneteinek csökkentését. A problémamegoldás stratégiájának ellentmondásos hatása van. A hatékony problémamegoldás egyaránt növeli a személyes teljesítményt és a deperszonalizációt. Így hozzájárul ugyan a munkavállaló munkabírásának növeléséhez, de a cinizmus kialakítását is elősegíti. Egyes vizsgálatok összefüggést találnak az érzelemfókuszú megküzdés és a kiégés deperszonalizációs komponensének növekedése között, más vizsgálatok csak az összefüggés hiányát erősítik meg a kiégéssel és a depresszióval (áttekintés: MÉszÁros, CSERHÁTI és mtsai, 2013).

Az egészségügyben többféle stresszcsökkentő intervenciót kipróbáltak. MARINE, RUOTSALAINEN, SERRA és VERBECK (2014) a munkastressz csökkentését célzó vizsgálatok metaanalízisét végezték el. 14 randomizált kontrollált vizsgálat volt, emellett három cluster-randomizált és két „crossover” tanulmányt értékeltek, 1564 
résztvevővel az intervenciós csoportokból, 1248 kontrollszeméllyel. Az intervenciókat két csoportra osztották: személyorientált és munkaorientált módszerekre. A személyre vonatkozó intervenciók között a kognitív-viselkedésterápiás tréningeket, relaxációt, zeneterápiát, terápiás masszázst alkalmazták, de voltak többkomponensű programok is. A munkahelyet célzó intervenciók attitűdváltoztatásra, a kommunikáció javítására, a kollegiális támogatásra, a résztvevői problémamegoldásra és döntéshozatalra, valamint a munkaszervezés változtatásaira törekedtek. A szerzők összefoglalóan azt találták, hogy korlátozott értékủ bizonyítékok vannak mind a két típusú intervenciók előnyös hatására vonatkozóan. A személyre orientált intervenciók csökkentették a stresszt, a kiégés faktorai közül az emocionális kimerülést és a személyes teljesítménycsökkenést, továbbá mind az állapot-, mind a vonásszorongást. Egy vizsgálat szerint a kiégés tünetei két éven át is csökkentek maradtak emlékeztető ülésekkel segítve a tartósságot. A munkára irányuló intervenciók csökkentették a stressztüneteket és a deperszonalizációt, de egy vizsgálat szerint az eredmények nem voltak tartósak hathónapos utánkövetéssel értékelve.

Igen fontos az ápolószemélyzet stresszcsökkentése és kiégésének megelőzése. MimuRA és GRIFFITHS (2003) az ápolók munkahelyi stresszcsökkentésére vonatkozó tíz kutatást tekintett át, közöttük hét randomizált és kontrollált, három prospektív kohorsz vizsgálat volt. Ezekben a következő módszereket alkalmazták többkevesebb hatékonysággal: személyekre vonatkozóan edukációs programokat, szerepjátékokat, relaxációt, zenét, testgyakorlatokat, humort, kognitív technikákat. A vizsgálatok gyenge minőségűek voltak. A személyes támogatást nyújtó programok hatékonyságát több bizonyíték támasztotta alá, mint a környezeti stresszorok csökkentését célzó programokét. A szerzők további, jól tervezett kutatásokat sürgetnek, hogy megfelelő ajánlásokkal lehessen élni. LIGHT IRIN és BINCY (2012) indiai ápolók körében folytattak egy vizsgálatot a stresszmenedzsment hatékonyságának mérésére. Stresszcsökkentésre a következő módszereket alkalmazták: a munkahelyi stressz tudatossága, asszertív tréning, időmenedzsment, progresszív relaxáció. $\mathrm{Az}$ eredmények szerint a legnagyobb stresszforrás a betegellátás, az általános munkakövetelmények és a munkaterhelés volt. A program során a súlyos stressz szintje 60\%-ról 20\%-ra csökkent.

A pszichiátria területén dolgozókra vonatkozó néhány korábbi kutatás tanulságait összegezve GÜNTHNER és BATRA (2012) felhívja a figyelmet arra, hogy nem minden módszer hatékony, például a személyes fejlődést segítő csoportprogram nem segítette a kiégés dimenzióinak változását. Az ápolószemélyzet számára hasznos a specifikus magatartástréning, ami elsősorban az ápolási feladatokra irányul, s növeli a munkaelégedettséget, csökkenti a stresszt és a megbetegedések számát (EDWARDS és BURNARD, 2003). Az esetmegbeszélő csoportok is igen hasznosak (meg kell említenünk a Bálint-csoportok előnyös szerepét). Egy randomizált, kontrollált vizsgálatban a sorstárssegítő csoportok működését hatékonynak találták a kiégés megelőzésében (Peterson, Bergström, SAMUelsson, Asberg és NYGREN, 2008). Az empátiafejlesztő tréningek is jelentősen csökkentették a kiégés tüneteit. Stresszmenedzsment-csoportokat is szerveztek, amelyekben relaxáció és esetmegbeszélés folyt. Az egyénekre alkalmazott technikák között a relaxációk, a meditáció, az önhipnózis, a biofeedback csökkentette a stresszt. 
Igen fontos a fizikai aktivitás fenntartása a kiégés megelőzésében. Ennek sokirányú előnyös hatását jól ismerjük, például a depresszió kezelésére kiadott szakmai útmutatók is tartalmaznak ilyen ajánlást (Work Group on Major Depressive Disorder, 2010). A leggyakrabban a futást (vagy gyaloglást, például az újabban terjedő nordic walkingot), a kerékpározást, az úszást, a jógát, az aerobicot vagy az edzőtermi erősítést ajánlják. A testedzés hangulati hatásainak hátterében jól ismertek a biológiai következmények, a neurotranszmitterek és neuromodulátorok változásai, például az endorfinok szintjének növekedése. A pszichológiai hatások mellett fontos a testtömeg-index csökkentése, a kardiovaszkuláris rendszer és a mozgásszervek betegségeinek megelőzése is. Lényeges a világos célok kitűzése, lehetőleg társak találása a tevékenységhez, s a rendszeresség. Érdemes áttekinteni egy alapos vizsgálat eredményeit: WEIGHT és munkatársai (2013) testedzési program hatását vizsgálták a fizikai aktivitásra, az életminőségre, valamint a kiégésre egy nagy egészségügyi központ orvosai között. A csoportközpontú program 12 hetes volt. A vizsgált 628 orvosnak csupán 31\%-a teljesítette az USA egészségügyi minisztériumi ajánlásait a fizikai aktivitásra vonatkozóan, s 29\%-uknak legalább hetente ismétlődő kiégési tünetei voltak. A programot elvégző orvosok 48\%-a felelt meg a fizikai aktivitásra vonatkozó ajánlásoknak, míg a programot nem vállalóknak csak 23\%-a. Az életminőség javult, a kiégés alacsonyabb volt a résztvevők körében, mint a programot nem vállalók között (24\% vs. $29 \%)$, de ez nem volt szignifikáns különbség.

\section{A stresszmenedzsment újabb lehetöségei (a mindfulness, a reziliencia és a humor szerepe)}

Az újabb módszerek közül elsősorban a tudatos jelenléten (mindfulness) alapuló technikákat említjük. Az egyre inkább a szakmai érdeklődés előterében kerülő módszer három technikából épül fel: testészlelés („body scan”), ülő meditáció, hatha jóga (KABAT-ZINN, 2003). A mindfulness-alapú stresszcsökkentés egészségesekben is hasznos (áttekintés: CHIESA és SERRETTI, 2009). Az egészségügy területén a mindfulness az ápolók kiégésének csökkentésében igen jó, mert a meditáció révén a karrierjük és a személyes életük fölötti kontrollt is jobban képesek gyakorolni (DAVIES, 2008). Egészségügyi főiskolások között alkalmazták a mindfulness-alapú stresszcsökkentést (BARBOSA és mtsai, 2013). Bár az elemszám kicsi volt (13 fö, valamint 15 fös kontrollcsoport), az eredmények szerint a módszer csökkentette a szorongást és növelte az empátiát a hallgatók között. Ide tartozik, hogy ELDER, Nidich, MORIARTY és Nidich (2014) transzcendentális meditációt alkalmaztak hatékonyan a distressz és a kiégés csökkentésére viselkedészavaros fiatalok nevelőotthonának dolgozói között. Az eredmények szerint a módszer hatékonysága a standard relaxációs módszerekkel egyenértékű, ugyanakkor az empátiát és az önmagunkra irányuló figyelmet is fokozza. Még hiányzanak a hosszú távú vizsgálatok a hatékonyság tartósságára vonatkozóan.

Fontos szempontot jelent a kiégés megelőzésében a reziliencia (rugalmasság) növelése. A rezilienciát fokozó stratégiák a coping viselkedéseket erősítik. Minden 
segítő foglalkozásban hasznosak lehetnek, egy program a munkába lépő ápolók számára volt eredményes (RICHEZ, 2014). BigLAN, LAYTON, JONES, HANKIns és RUSBY (2013) fejlődési elmaradással rendelkező gyermekekkel foglalkozó nevelők kiégését értékelték. Randomizált várólistás elrendezésben a pszichológiai flexibilitást növelő „elfogadás és elköteleződés terápiát (ACT)” alkalmaztak, ami csökkentette a személyzet élménykerülését, fokozta a tudatos jelenlétet, az élet értelmébe vetett hitet és az énhatékonyság érzését. Úgy tűnik tehát, hogy a reziliencia növelése a kiégésmegelőzés egyik célpontja lehet.

A humor stresszcsökkentő hatását természetesen régóta ismerjük, de kifejezetten munkastresszcsökkentésre és kiégésmegelőzésre csak újabban alkalmazzák. A humor hatásmechanizmusa munkalélektani szempontból elsősorban az énerősítő és a kapcsolatokat erősítő szerep. Egy kutatásban 1200, nem egészségügyi alkalmazott körében vizsgálták a humor jelentőségét, s azt találták, hogy az énerősítő és az affiliatív humor pozitív összefüggést mutatott a munkabeli elkötelezettséggel, különösen akkor, ha a társas támogatás alacsony volt (VAN DEN BROECK, VAN DER Elst, Dikkers, LANGe és De WiTte, 2012). A humor a dolgozók jóllétéhez jelentős mértékben hozzájárul, növeli a személyes erőforrásokat, csökkenti a szerepkonfliktusokat és a munkahelyi kihívásokat (például a munkaterhelést); csökkenti a kiégés veszélyét és növeli a munkabeli elköteleződést. Ezek a megfigyelések az egészségügy keretei között is megfontolandók, bár az általános munkastressz körében készültek a következtetések levonását lehetővé tevő kutatások.

\section{A modern információs technológiák a kiégés megelözésében}

A kiégés megelőzésében és kezelésében megjelentek a modern információs technológiák is. Eddig kevés kontrollált tanulmány született az egészségügyi dolgozók kiégésének megelőzését szolgáló e legújabb módszerek köréből, ennek ellenére fontosnak érezzük a lehetőségek bemutatását a módszerek várhatóan gyors elterjedése miatt.

Röviden tekintsük át a modern információs technológiák alkalmazását a (mentális) egészségügyben. Az utóbbi egy-két évtizedben kialakult az „e-health”, ezen belül az „e-mental health”, s ennek részeként az „e-terápia”. Összefoglaló névként a telemedicina vált közkeletűvé: a telekommunikációs eszközök orvosi felhasználása egészségügyi szakemberek által - azaz a betegek egymás közötti kapcsolattartása például a közösségi weboldalakon nem tartozik ide, bár az önsegítésben szerepük lehet (Purebl, Güleç és Mezei, 2012; Túry, GÜleç és Purebl, 2014). A számítógépek és okostelefonok sokféle egészségügyi alkalmazással szolgálják az egészségvédelmet. Az új módszerek segítségével a rejtőzködő személyek jobban elérhetők. Lényeges szempont, hogy a telemedicina hatósugara nagy, a költséghatékonyság pedig igen jó. További értékük az, hogy a személyre szabott ellátási formák kitűnően alkalmazhatók. Ma még meg kell állapítani, hogy e gyorsan fejlődő területen kevés jól kontrollált vizsgálat született. Az e-mental health területére vonatkozó programok mintegy harmadában történt randomizált vizsgálaton alapuló értékelés. Kiemelendő, hogy a face-to-face interjúk és a videokonferencia se- 
gítségével folytatott interjúk eredménye csaknem teljesen egyezik (CHRISTENSEN és Petrie, 2013; Deslich, Stec, Tomblin és Coustasse, 2013).

Az új technológiák bizonyos hátrányokkal is járhatnak. Ennek legfőbb példái: a kontrollhiány vagy a rejtőzködés torzítja az identitást; a társas támogatás mellett szubkultúra alakulhat ki; a technikai készségek különbségei gátlóak lehetnek; kompetenciabeli és etikai kérdések is felmerülnek. Fontos, hogy a közvetlen emberi ellátás igénye ne szoruljon háttérbe, a kliensek ne érezzenek személytelenséget az új eszközök alkalmazása során (TúRY, GÜLEÇ és PUREBL, 2014).

Elsősorban a következő eszközök alkalmazhatók telemedicinális céllal a mentális egészségügyben (mindegyiküknél könnyen belátható, milyen szerepük lehet a kiégés prevenciójában). A mobiltelefont, illetve az okostelefont például SMS-ekben küldött rövid kérdőívekre lehet használni szűrő célzattal. A számítógépek sokféle alkalmazása ismert, például edukációs céllal, vagy önsegítésre. A hordozható számítógépek (laptop, I-pad) alkalmasak az önmonitorozásra. A virtuális valóság interaktív, multimédiás programok útján sok pszichés tünet módosítására teremt lehetőséget (például fóbiák leküzdésére, az asszertivitás fokozására). Az internet az e-mailtől kezdve a videotelefonig a személyes kapcsolattartás különböző változataiban használható. E-mailen rendszeres írásbeli feladatok adhatók. Szinkron kommunikációra teremt lehetőséget az internetes csevegés (chat), aszinkron interakcióra a fórumok és üzenőfalak. Az internetes multimédiás programok is jó lehetőséget teremtenek a prevencióra és az önsegítésre. Nagy előnyük ezen eszközöknek, hogy a terápiás kontroll sokkal inkább a kliens kezében van, az önhatékonyság és kompetenciaérzés jobb. A szégyenérzés kevésbé játszik szerepet, a kliens láthatatlan és anonim maradhat. Természetesen nem arról van szó, hogy a telemedicina a hagyományos orvoslást teljesen helyettesíthetné, de kiegészítő szerepe növekszik (hazai összefoglaló: Túry, Güleç és PUREbL, 2014).

A stresszmenedzsment és a kiégés megelőzése terén ki kell emelni, hogy sokan használják az internetet stresszcsökkentésre: olvasásra, a közösségi oldalak olvasására, kapcsolatok ápolására, blogok készítésére, figyelemelterelő játékok (például sudoku) alkalmazására, zenehallgatásra, humoros oldalak felkeresésére stb. Mindezen túlmenően különböző programokat is készítettek a depresszió, a kiégés megelőzésére, életmód-változtatásra. Az első lépést az internetes edukációs anyagok jelentik. Vannak olyan edukációs webhelyek, amelyek a munka és a magánélet közötti egyensúly megteremtését segítik (ECKERMANN és HOWARD, 2008). Ezek konkrét segítséget jelentenek a munkastressz csökkentésében és a kiégés elkerülésében. A következő lépés a kockázatfelmérés. LAAN és munkatársai (2012) egy webalapú, munkahelyi egészségi kockázatfelmérő program protokolljáról számoltak be, amely személyre szabott feedbacket is magába foglalt az életmódról. Az adatfelvételre a vizsgálat kezdetén és hat hónap múlva került sor. Az így nyert információk hasznosak lehetnek a hatékony intervenciók tervezésében az alkalmazottak között. Sajnos, az adatok kiértékelését a program tervét bemutató előzetes közlemény még nem írta le.

A következőkben két konkrét példával illusztráljuk a telemedicinális eszközöknek a kiégésmegelőzésben szóba jövő lehetőségeit. VAN STRATEN, CujJPERs és SMITS (2008) webalapú, problémamegoldáson alapuló, önsegítő intervenciós 
programot fejlesztettek ki a depresszió, a szorongás és a munkastressz csökkentésére. A program kognitív-viselkedésterápiás alapú, az intervenciók központi eleme a megoldható problémák kezelésének strukturált módszere volt. Ennek hatékonyságát randomizált vizsgálatban értékelték, a 107 fős intervenciós csoportot 106 fős várólistás kontrollcsoporttal összehasonlítva. Az intervenciós csoportból a teljes programot csak 59 személy fejezte be. Az internetalapú négyhetes program során minden héten automatikus e-mailt kaptak a résztvevők a következő hét anyagának tartalmáról és gyakorlatairól. Emellett személyes támogatásban is részesültek kiképzett pszichológushallgatóktól, akik a végzett gyakorlatokról visszajelzést adtak. E program hatékony volt a depresszió és a szorongás tüneteinek csökkentésében, valamint az életminőség javításában. Kevésbé volt hatékony a munkastressz csökkentésében, de az intervenciós csoport tagjai gyakrabban felépültek a kiégés tüneteiből, mint a kontrollcsoport tagjai. Egy másik vizsgálat során webalapú asszertív tréninget dolgoztak ki ápolónők stresszmenedzselésére (YAMAGISHI és mtsai, 2007). A hetvenperces program három héten át tartott. Az asszertív viselkedés nőtt a tréning végén, és magas maradt egyhónapos utánkövetés során is. A mentális munkaterhelés csökkent. Bár a vizsgálatot csak 25 ápolónőn végezték, az eredmények biztatónak látszanak.

E vizsgálatok arról tanúskodnak, hogy a kiégés prevenciója érdekében a telemedicinális módszerek jól használhatók tanácsadásra, edukációra, stresszkezelésre, vagy speciális programok meghonosítására. A lehetőségek még nincsenek kihasználva - ezt illusztrálandó néhány olyan kutatást idézünk, amelyek módszerei könnyen átültethetők volnának a kiégés prevenciójának területére. Leginkább a depresszió és az öngyilkosság terén találunk ilyen komplex programokat (ez érthető a kiégés és a depresszió kapcsolatából). Egy kutatásban orvosi egyetemen alkalmaztak szuicidiumprevenciós és a depresszió felismerését célzó internetes programot a hallgatók és az orvosok számára. Ennek két része volt: az egyik a szűrést, értékelést és beutalást jelentette, a másik pedig egyetemi pszichoedukációs kampányt. A webalapú szűrés anonim módon történt. A program első évében 2860 személy kapott e-mailen értesítést, 374 (13\%) töltötte ki a szűrő kérdőívet, akiknek 27\%-a (101 személy) teljesítette a depresszió vagy a szuicidium jelentős kockázatának kritériumait, és 13\% (48 személy) kapott beutalót a mentális egészségi állapot értékelésére és kezelésre (MOUTIER és mtsai, 2012).

Több olyan hazai program ismert, amely nemzetközi együttműködéssel létesült, s ilyen módszerekkel él különböző pszichiátriai zavarokban, így például a depresszió és az öngyilkosság megelőzésében, az evészavarok megelőzésében és utókezelésében (GÜLEÇ, KOHLS és TÚRY, 2011). E programok komponensei általában a következők:

- Online pszichoedukációs, információs anyagok.

- Multimédiás pszichoterápiás ülések (rendszerint kognitív viselkedésterápia).

- Egyéni támogatás e-mailen vagy chat formájában.

- Társas támogatás szinkron vagy aszinkron módon (chat, fórumok stb.).

- Tünetmonitorozás, amelyet visszajelzés adása követ. 
A modern információs eszközök a diagnosztikus és terápiás eszköztár fejlesztését jelentik - leírták például az internet-alapú kognitív viselkedésterápiákat (ICBT). Egyre több vizsgálat igazolja a telemedicinális módszerek hatékonyságát. BARAK, HEN, BONIEL-Nissim és SHAPIRA (2008) alapos metaanalízise szerint az online módszerek hatásmérete hasonló a hagyományos pszichoterápiákéhoz.

\section{KONKLÚZIÓ}

A munkalélektanban és a segítő foglalkozások működésének értékelésében a kiégés szerepe kulcsfontosságúvá vált. Egyaránt lényeges a kockázatnak kitett egyén (szakember) érdekében és a segített személyek ellátásának szempontjából is. Az egészségügyi gazdaságossági szempontok kiemelendők: a jó mentális és testi állapotban lévő munkaerő hatékonyabb, s a kiégéstől szenvedők ellátásának költségei hosszú távon bőségesen megtérülnek.

A kiégés elsődleges, másodlagos és harmadlagos prevenciójában többféle hagyományos módszert alkalmaznak (ilyenek többek között a relaxációk, vagy a klasszikus kognitív-viselkedésterápiás stratégiák, mint például az asszertivitás növelése). Az újabb eljárások között a stresszmenedzsment különböző programjait kell kiemelnünk. Ezekben szerepet kapnak az újabb kognitív terápiás megoldások, a mindfulness stb. A megelőzés legújabb irányzatát a modern információs technológia vívmányai jelentik. Ma már számos erre alapuló program készült, elterjedésük várható. A jól kidolgozott megelőző programok hatékonyságát is mérik, bár a randomizált kutatások száma még szerény. A programokat egyre inkább személyre szabottan alkalmazzák, de mind több a szervezeti szintű megelőző program is.

A kiégés megelőzésében alkalmazható stresszmenedzsment hasznának összefoglalásaképpen GÜNTHNER és BATRA (2012) ajánlásait érdemes idézni:

1. A személyre szabott stresszmenedzsment programok intenzívek és tartósak legyenek (legalább öt hétig célszerű ezeket folytatni).

2. A proaktív kognitív-viselkedésterápiás technikák igen előnyösek.

3. A munkával kapcsolatos specifikus terhelést csökkenteni lehet a tevékenységhez tartozó ismeretek és készségek közvetítésével.

4. A körülírt terhelési helyzetek okozta stressz csökkentésében célzott kognitívviselkedésterápiás tréning ajánlott.

5. Ha a stresszorok nem kerülhetők el, akkor ezek pufferelése relaxációs és meditációs gyakorlatokkal, mindfulness-alapú módszerekkel segíthető.

6. A sikeres stresszmenedzsment fenntartása érdekében a környezeti feltételek megváltoztatása a program lebonyolítása után is lényeges. Emlékeztető csoportülések is hasznosak e szempontból.

PTACEK és munkatársai (2013) a kiégés megelőzésében és kezelésében az integratív stratégiát szorgalmazzák (amivel messzemenően egyetérhetünk). A szerzők szerint felhasználhatók a viselkedéses és kognitív módszerek, a testedzés, a relaxá- 
ciók, a táplálkozási intervenciók, a társas támogatás és a spiritualitás. Értékelik a szindróma élettani és neurobiológiai hátterét is, az örömszerző és jutalmazó mechanizmusokat. Ezek alapján szükség esetén farmakológiai beavatkozásra is sor kerülhet - természetesen a megfelelő tüneti és terápiás kritériumok fennállása esetén. Többkomponensű kiégésmegelőző programot ír le BERGNER (2012), amelyben stresszcsökkentő és kognitív elemek vannak. Az integratív programok általában a lépcsőzetes ellátás elve alapján működnek (BERGER, GRAVERT, SCHNELLER és MAIER, 2013). A munkahelyi egészségmenedzselésnek a következő fokozatai vannak: edukáció, a túlterhelés felismerése, egyéni támogatás, lépcsőzetes ellátás (háziorvos - szakorvos - pszichoterápia - integrált ellátás), visszailleszkedés.

Fontos feladat a szervezeti kultúra fejlesztése a segítő foglalkozások terén. Az új módszerek alkalmazására vonatkozó intézményi ellenállás leküzdése is lényeges, ennek elérése országos jelentőségű egészségpolitikai lépésekkel valósulhat meg.

\section{IRODALOM}

ÁDÁM, Sz. (2013). Work-family conflict among female and male physicians in Hungary: prevalence, stressor predictors and potential consequences on physicians well-being. Budapest: Pálúr Kft.

ÁdÁM Sz., GYŐRFFY Zs. és CsOBOTH Cs. (2006). Kiégés (burnout) szindróma az orvosi hivatásban. Hippocrates, 8(2), 113-117.

Ádám Sz., TORZSA P., GYőRfFy Zs., VÖRÖS K. és Kalabay L. (2009). Gyakori a magas fokú kiégés a háziorvosok és a háziorvosi rezidensek körében. Orvosi Hetilap, 150(7), 317-323.

ÁdÁm Sz., GYőrfFy Zs., Harmatta J., Túry F., Kopp M. és SzénYei G. (2010). A magyarországi pszichiáterek egészségi állapota. Psychiatria Hungarica, 25(1), 55-61.

Barak, A., Hen, L., Boniel-Nissim, M., \& Shapira, N. (2008). A comprehensive review and a metaanalysis of the effectiveness of internet-based psychotherapeutic interventions. Journal of Technology in Human Services, 26(2-4), 109-160.

Barbosa, P., Raymond, G., Zlotnick, C., Wilk, J., Toomey, R., \& Mitchell, J. (2013). Mindfulness-based stress reduction training is associated with greater empathy and reduced anxiety for graduate healthcare students. Education for Health (Abingdon, England), 26(1), 9-14.

Berger, M., Gravert, C., Schneller, C., \& Maier, W. (2013). Prävention und Behandlung psychischer Störungen am Arbeitsplatz. Nervenarzt, 84(11), 1291-1298.

Bergner, T. M. H. (2012). Burnout. A kiégés megelözése 12 lépésben. Budapest: Z-Press.

Biglan, A., Layton, G. L., Jones, L. B., Hankins, M., \& Rusby, J. C. (2013). The value of workshops on psychological flexibility for early childhood special education staff. Topics in Early Childhood Special Education, 32(4), 196-210.

Chiesa, A., \& Serretti, A. (2009). Mindfulness-based stress reduction for stress management in healthy people: a review and meta-analysis. Journal of Alternative and Complementary Medicine, 15(5), 593-600.

Christensen, H., \& Petrie, K. (2013). State of the e-mental health field in Australia: where are we now? Australian and New Zealand Journal of Psychiatry, 47(2), 117-120.

DAvies, W. R. (2008). Mindful meditation: healing burnout in critical care nursing. Holistic Nursing Practice, 22(1), 32-36. 
Deslich, S., Stec, B., Tomblin, S., \& Coustasse, A. (2013). Telepsychiatry in the 21 st century: transforming healthcare with technology. Perspectives in Health Information Management, 10(Summer). Published online Jul 1, 2013. PMCID: PMC3709879

Dyrbye, L. N., Varkey, P., Boone, S. L., Satele, D. V., Sloan, J. A., \& Shanafelt, T. D. (2013). Physician satisfaction and burnout at different career stages. Mayo Clinic Proceedings, 88(12), 1358-1367.

ECKermanN, S., \& HowARD, S. (2008). Health workforce crisis: how to achieve a work-life balance. Australian Journal of Rural Health, 16(2), 117.

EdWARds, D., \& Burnard, P. (2003). A systematic review of stress and stress management interventions for mental health nurses. Journal of Advanced Nursing, 42(2), 169-200.

Elder, C., Nidich, S., Moriarty, F., \& Nidich, R. (2014). Effect of transcendental meditation on employee stress, depression, and burnout: a randomized controlled study. Permanent Journal, 18(1), 19-23.

Freudenberger, H. J. (1974). Staff burn-out. Journal of Social Issues, 30(1), 159-175.

Guest, R. S., Baser, R., Li, Y., Scardino, P. T., Brown, A. E., \& Kissane, D. W. (2011). Cancer surgeons' distress and well-being, II: modifiable factors and the potential for organizational interventions. Annals of Surgical Oncology, 18(5), 1236-1242.

GÜleÇ, H., Kohls, E., \& Túry, F. (2011). New technologies in the treatment of patients with eating disorders. In Túry F. és PÁszTHY B. (szerk.), Az evészavarok pszichoterápiájának aktuális kérdései (89-114). Budapest: Semmelweis.

GÜnthner, A., \& BATrA, A. (2012). Stressmanagement als Burn-out-Prophylaxe. Bundesgesundheitsblatt - Gesundheitsforschung - Gesundheitsschutz, 55(2), 183-189.

GYŐRFFY Zs. és ÁDÁM Sz. (2004). Az egészségi állapot, a munkastressz és a kiégés alakulása az orvosi hivatásban. Szociológiai Szemle, 11(3), 107-127.

Harmatta J., ÁdÁm Sz., GyŐrfFy Zs., Túry F. és SzÉNYei G. (2010). A munkamegterhelés és a munkával kapcsolatos stressztényezők a magyarországi pszichiáterek körében. Psychiatria Hungarica, 25(5), 417-424.

Hem, E., Haldorsen, T., Aasland, O. G., Tyssen, R., Valgum, P., \& Ekeberg, O. (2004). Suicide among physicians. American Journal of Psychiatry, 161(11), 2295-2302.

Kabat-Zinn, J. (2003). Mindfulness-based stress reduction (MBSR). Constructivism in the Human Sciences, 8(2), 73-107.

Laan, E. K., Kraajenhagen, R. A., Peek, N., Busschers, W. B., Deutekom, M., Bossuyt, P. M. et al. (2012). Effectiveness of a web-based health risk assessment with individuallytailored feedback on lifestyle behaviour: study protocol. BioMed Central, Public Health, $12,200$.

Light IRIN, C., \& BinCY, R. (2012). Effect of stress management interventions on job stress among nurses working in critical care units. The Nursing Journal of India, 103(6), 269271.

MajOr J., Ress K., Hulesch B. és Túry F. (2006). A kiégés jelensége az orvosi hivatásban. Lege Artis Medicinae, 16(4), 367-373.

Marine, A., Ruotsalainen, M. A., Serra, C., \& Verbeck, J. H. (2014). Preventing occupational stress in healthcare workers. Cochrane Database of Systematic Reviews, 11, CD001892.

Maslach, C., \& Leiter, M. (1997). The truth about burnout. How organizations cause personal stress and what to do about it. San Francisco: Jossey-Bass Publishers. 
MÉSZÁROS V. (2012). A gyógyítók egészsége: a kiégés és a kiégés megelőzése, illetve kezelése. In Urbán R., Demetrovics Zs., Rigó A. és OláH A. (szerk.), Az egészségpszichológia elmélete és alkalmazása II. (219-250). Budapest: ELTE Eötvös Kiadó.

Mészáros V., Cserháti Z., Oláh A., Perczel Forintos D. és Ádám Sz. (2013). A munkahelyi stresszel való megküzdés egészségügyi szakdolgozók körében - lehetőségek a kiégés és depresszió megelőzésének szolgálatában. Orvosi Hetilap, 154(12), 449-454.

Mimura, C., \& Griffiths, P. (2003). The effectiveness of current approaches to workplace stress management in the nursing profession: an evidence based literature review. Occupational and Environmental Medicine, 60, 10-15.

Moutier, C., Norcross, W., Jong, P., Norman, M., Kirby, B., McGuire, T. et al. (2012). The suicide prevention and depression awareness program at the University of California, San Diego School of Medicine. Academic Medicine, 87(3), 320-326.

PAPP B. és LÁNG A. (2013). Tanárok öngyilkossággal kapcsolatos ismeretei, különös tekintettel a kiégésre és az elkerülő megküzdésre. Psychiatria Hungarica, 28(3), 229-238.

PAPP Sz., \& TÚRY F. (2010). A pályakezdő orvosok jövőképe és egészségi állapota. Lege Artis Medicinae, 20(6-7), 423-429.

PÁlfi, I., Németh, K., Kerekes, Zs., Kállai, J., \& Bethlehem, J. (2008). The role of burnout among Hungarian nurses. International Journal of Nursing Practice, 14(1), 19-25.

Pálfiné Szabó I., VRanesicsné Horváth I., Németh K. és Bethlehem J. (2007). Az ápolók mentálhigiénés állapota, és a kiégés szindrómát provokáló faktorok előfordulása a vizsgált populációban. Növér, 20(4), 3-13.

Peterson, U., Bergström, G., SAmuelsson, M., Asberg, M., Nygren, A. (2008). Reflecting peer-support groups in the prevention of stress and burnout: randomized controlled trial. Journal of Advanced Nursing, 63(5), 506-516.

Ptacek, R., Stefano, G. B., Kuzelova, H., Raboch, J., Harsa, P., Kream, R. M. (2013). Burnout syndrome in medical professionals: a manifestation of chronic stress with counterintuitive passive characterisctics. Neuroendocrinology Letters, 34(4), 259-264.

Purebl Gy., Güleç, H. és Mezei Á. (2012). E-pszichoterápia. In Unoka Zs., Purebl Gy., TÚry F. és BiTTER I. (szerk.), Pszichoterápia az orvosi gyakorlatban (256-260). Budapest: Semmelweis.

Queiros, C., Carlotto, M. S., Kaiseler, M., Dias, S., \& Pereira, A. M. (2013). Predictors of burnout among nurses: an interactionist approach. Psicothema, 25(3), 330-335.

Richardson, K. M., \& Rothstein, H. R. (2008). Effects of occupational stress management intervention programs: a meta-analysis. Journal of Occupational Health Psychology, 13(1), 69-93.

Richez, M. (2014). Resilience-building strategies for nurses in transition. Journal of Continuing Education in Nursing, 45(2), 54-55.

Shanafelt, T. D., Sloan, J. A., \& Habermann, T. M. (2003). The well-being of physicians. American Journal of Medicine, 114(6), 513-519.

SusÁNSZKY É., HajNAL Á. és KOPP M. (2008). Öngyilkossággal kapcsolatos ismeretek, attitűdök a magyar lakosság és segítő foglalkozású szakemberek körében. Psychiatria Hungarica, 23(5), 376-384.

Swetz, K. M., Harrington, S. E., Matsuyama, R. K., Shanafelt, T. D., \& Lyckholm, L. J. (2009). Strategies for avoiding burnout in hospice and palliative medicine: peer advice for physicians on achieving longevity and fulfillment. Journal of Palliative Medicine, 12(9), 773-777. 
Túry F., Güleç, H. és Purebl Gy. (2015). Telemedicina a pszichiátriában - a modern információs technológia szerepe. In FürEDI J. és NÉMETH A. (szerk.), A pszichiátria magyar kézikönyve (5., átdolgozott kiadás). Budapest: Medicina.

Van den Broeck, A., Van der Elst, T., Dikkers, J., De Lange, A., \& De Witte, H. (2012). This is funny: on the beneficial role of self-enhancing and affiliative humour in job design. Psicothema, 24(1), 87-93.

VAn der Klink, J. J. L., Blonk, R. W. B., Schene, A. H., \& Van Dijk, F. J. H. (2001). The benefits of interventions for work-related stress. American Journal of Public Health, 91(2), 270-276.

Van Straten, A., Cujjpers, P., \& Smits, N. (2008). Effectiveness of a web-based self-help intervention for symptoms of depression, anxiety, and stress: randomized controlled trial. Journal of Medical Internet Research, 25, 10(1):e7.

Weight, C. J., Sellon, J. L., Lessard-Anderson, C. R., Shanafelt, T. D., Olsen, K. D., \& LASKOWSKI, E. R. (2013). Physical activity, quality of life, and burnout among physician trainees: the effect of a team-based, incentivized exercise program. Mayo Clinic Proceedings, 88(12), 1435-1442.

Wiggleton, C., Petrusa, E., Loomis, K., Tarpley, J., Tarpley, M., O’Gorman, M. L. et al. (2010). Medical students' experiences of moral distress: development of a web-based survey. Academic Medicine, 85(1), 111-117.

Winwood, P. C., BAKKer, A. B., \& Winefield, A. H. (2007). An investigation of the role of non-work-time behavior in buffering the effects of work strain. Journal of Occupational and Environmental Medicine, 49(8), 862-871.

Work Group on Major Depressive Disorder (2010). American Psychiatric Association: Practice guideline for the treatment of patients with major depressive disorder. Third edition. American Journal of Psychiatry, 167(10): Suppl.

Yamagishi, M., Kobayashi, T., Kobayashi, T., Nagami, M., Shimazu, A., \& Kageyama, T. (2007). Effect of web-based assertion training for stress management of Japanese nurses. Journal of Nurse Management, 15(6), 603-607.

\title{
PREVENTION OF BURNOUT SYNDROME - FROM THE TRADITIONS TO THE MODERN INFORMATION TECHNOLOGIES
}

\author{
SZÉNYEI, GÁBOR ANDRÁS - ÁDÁM, SZILVIA - GYŐRFFY, ZSUZSA - TÚRY, FERENC
}

Aim: Burn-out is a common syndrome of helpers, which leads to individual burdens and the difficulties of the health system. Its prevention is of basic importance both in individual and organizational level. In our review the newer methods of the burn-out prevention are summarized.

Methods: Review of the data in literature from the last decade. Mainly the research demonstrating recent procedures and efficacy studies are presented (e.g., studies relating to the e-mental health).

Results: In the primary, secondary and tertiary prevention traditional methods are frequently applied (e.g., relaxation, cognitive behavioural elements). Among the newer techniques the stress management, and the mindfulness-based programs should be mentioned. The most modern tools are the new information technologies, which are used in more and more prevention programs. Among the new 
prevention strategies the individually tailored methods, and the programs relating on the improvement of the organizational culture have important role. The latter call the attention to the need for health policy measures.

Conclusion: The prevention of burn-out syndrome is an essential task in the work psychology and among helpers, to defend the professionals and the quality of the health care, and from the point of view of the health economics. The efficacy of the prevention programs is good, although only a few randomized, controlled trials are available.

Key words: $\quad$ burn-out, job stress, prevention, stress management, e-mental health 